\title{
Pattern of Depression Among Patients of Myocardial Infarction in Karachi, Pakistan: A Cross-sectional Study
} Hasham Saeed ${ }^{1}$, Fahad Khan ${ }^{2}$, Syeda Fatima Mohsin ${ }^{3}$, Farwa Haider Qizilbash ${ }^{3}$, Tayyab Raza Fraz ${ }^{4}$,
Qirat Jawed ${ }^{3}$, Nawaz Lashari ${ }^{5}$

1. Internal Medicine, Dow Medical College and Civil Hospital, Karachi, PAK 2. Cardiology, Civil Hospital Karachi, Karachi, PAK 3. Student, Dow Medical College and Civil Hospital, Karachi, PAK 4. Statistics, University of Karachi, Karachi, PAK 5. Cardiology, Civil Hospital, Karachi, PAK

Corresponding author: Hasham Saeed, saeed.hasham@outlook.com

\section{Abstract \\ Background}

Depression is a well-known risk factor that aggravates the chances of having various complications of acute coronary syndrome (ACS) such as cardiovascular collapse, heart failure, arrhythmia, recurrent myocardial infarction, and stroke among patients of ACS. ACS is a broad term which includes unstable angina as well as myocardial infarction (MI). The purpose of this study is to analyze the prevalence of depression among the patients of MI admitted to the tertiary care hospitals of Karachi, Pakistan.

\section{Methods and materials}

A hospital-based, cross-sectional study was conducted in which 375 admitted and diagnosed patients of MI with a mean age of 58 years were interviewed at the cardiology department of the Civil Hospital and National Institute of Cardio-Vascular Diseases (NICVD) Hospital, Karachi, from June to November 2017 using a self-made validated questionnaire, including patient health questionnaire-9 (PHQ-9).

\section{Results}

Overall, about $12.8 \%$ of the cases were screened positive for severe depression, $17.1 \%$ for moderately severe depression, $17.6 \%$ for moderate depression, and $32 \%$ for mild depression (total of $79.5 \%$ ). Of 146 female subjects, $119(81.5 \%)$ were found to be suffering from some degree of depression while 179 (78.2\%) of the 229 males screened positive for some degree of depression. Furthermore, 79 (82.3\%) of the 96 smokers were suffering from a range of depression while 219 (78.5\%) of the 279 non-smokers suffered the same. In addition, the results of the PHQ-9 were cross-tabbed with age $(\mathrm{p}=0.34)$, gender $(\mathrm{p}=0.66)$, marital status $(\mathrm{p}=0.07)$, living status, smoking $(\mathrm{p}=0.72)$, hypertension $(\mathrm{p}=0.55)$, and diabetes $(\mathrm{p}=0.19)$.

Received 07/22/2018

Review began 07/23/2018 Review ended 08/21/2018 Published 08/24/2018

\section{() Copyright 2018}

Saeed et al. This is an open access article distributed under the terms of the Creative Commons Attribution License CC-BY 3.0., which permits unrestricted use, distribution, and reproduction in any medium, provided the original author and source are credited.

\section{Conclusion}

This study concludes that many of the patients of MI who were admitted to the tertiary care hospitals in Karachi, Pakistan, are suffering from major depressive behavioral changes following the cardiovascular event, which is known to aggravate the chances of having complications associated with it.

Categories: Cardiology, Preventive Medicine, Psychiatry

Keywords: acute coronary syndrome, acs, depression, outcome, complication, myocardial infarction, mi, smoking

\section{Introduction}

It is quite commonly observed that after a myocardial infarction (MI), cardiac surgery or procedure, recent hospitalization, or new diagnosis of heart disease, patients tend to get sad or depressed [1]. Temporary feelings of sadness are normal and should gradually go away within a few weeks. Sometimes, however, a depressed mood can prevent a patient from leading a normal life. When a depressed mood is severe and accompanied by other symptoms that persist every day for two or more weeks, it can deteriorate the patient's condition and aggravate the damage, increasing the risk of worsening the prognosis of acute coronary syndrome (ACS) by a factor of 1.6 to 2.7 -fold [2]; it can cause a $22 \%$ increased risk of all-cause mortality and a $13 \%$ increased risk of cardiovascular events [3]. This is due to several effects of unmanaged stress and depression like high blood pressure, arterial damage [4], irregular heart rhythms, weakened immune system, increased platelet activity [5], decreased heart rate variability, increased proinflammatory markers and cytokines [6-8] and negative lifestyle habits associated with depression (e.g., smoking, alcohol consumption, lack of exercise, poor diet, and isolation) [9-17]. Previous studies were conducted to analyze the prevalence of depression, post-MI, in developed countries and showed a dose-response relationship, with the severity of depression being associated with an earlier onset of complications [18-19]. 
A recent study based on the National Health Interview Survey (NHIS) data of 30,801 adults found the 12month prevalence of major depression to be $9.3 \%$ in individuals with cardiac disease as compared with $4.8 \%$ in those with no comorbid medical illness [20]. Depression has received formal recognition as a risk factor for poor prognosis in patients with ACS [1-2]. There is a lack of knowledge regarding the above-described relationships in developing countries. This study was conducted to look for the prevalence of depressive behavioral changes in the ACS patients of two tertiary care hospitals of Karachi, Pakistan. Illiteracy and a lack of awareness about aggravating factors, leading to a poor prognosis for ACS patients in developing countries, makes it difficult to get to ensure increased morbidity and mortality in such patients.

\section{Materials And Methods}

A hospital-based, cross-sectional study was conducted at two sites, namely the cardiology departments of the Civil Hospital and National Institute of Cardio-Vascular Diseases (NICVD) over a period of three months from June to November 2017. The sample size was found to be 375 for the population survey, taking a $95 \%$ confidence interval using OpenEpi data version 3.03 (Emory University, Rollins School of Public Health, Atlanta, Georgia) [21]. The questionnaire included the following three sections, i.e., demographics, past medical, drug and family history and depression screening scale. The demographics section included age, gender, marital status, education, and living alone or not. In the history section, patients were asked about their smoking habits, whether they were diagnosed cases of hypertension and/or diabetes, and their family history of diseases. For the last section of depression screening, patient health questionnaire-9 (PHQ-9) scale was incorporated (Figure 1).

\begin{tabular}{|c|c|c|c|c|}
\hline \multicolumn{5}{|c|}{ Nine Symptom Checkllst } \\
\hline \multicolumn{5}{|l|}{$\begin{array}{l}\text { Over the past } 2 \text { weeks, how often have you been } \\
\text { bothered by any of the following problems? }\end{array}$} \\
\hline & Not at all & Several days & $\begin{array}{l}\text { More than } \\
\text { half the days }\end{array}$ & $\begin{array}{l}\text { Nearly } \\
\text { every day }\end{array}$ \\
\hline 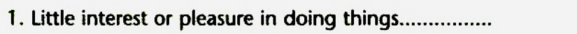 & 0 & 1 & 2 & 3 \\
\hline 2. Feeling down, depressed, or hopeless...................... & 0 & 1 & 2 & 3 \\
\hline 3. Trouble falling or staying asleep, or sleeping too much.......... & ... 0 & 1 & 2 & 3 \\
\hline 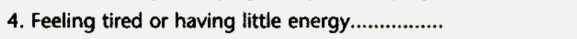 & 0 & 1 & 2 & 3 \\
\hline 5. Poor appetite or overeating................ & 0 & 1 & 2 & 3 \\
\hline $\begin{array}{l}\text { 6. Feeling bad about yourself - or that you are a } \\
\text { failure or have let yourself or your family down...... }\end{array}$ & 0 & 1 & 2 & 3 \\
\hline $\begin{array}{l}\text { 7. Trouble concentrating on things, such as reading } \\
\text { the newspaper or watching television...................... }\end{array}$ & 0 & 1 & 2 & 3 \\
\hline \multicolumn{5}{|l|}{$\begin{array}{l}\text { 8. Moving or speaking so slowly that other people } \\
\text { could have noticed? Or the opposite - being so } \\
\text { fidgety or restless that you have been moving }\end{array}$} \\
\hline \multicolumn{5}{|l|}{$\begin{array}{l}\text { 9. Thoughts that you would be better off dead or of } \\
\text { hurting yourself in some way.................... }\end{array}$} \\
\hline \multicolumn{5}{|c|}{ (For office coding: Total Score $\_=\ldots+\ldots+\ldots$ ) } \\
\hline \multicolumn{5}{|c|}{$\begin{array}{l}\text { If you checked off any problems, how difficult have these problems made it for you to do your work, take care of things at } \\
\text { home, or get along with other people? }\end{array}$} \\
\hline Somewhat difficult & \multicolumn{2}{|c|}{ Very difficult } & \multicolumn{2}{|c|}{ Extremely difficult } \\
\hline$\square$ & \multicolumn{2}{|c|}{$\square$} & \multicolumn{2}{|l|}{$\square$} \\
\hline \multicolumn{5}{|c|}{ 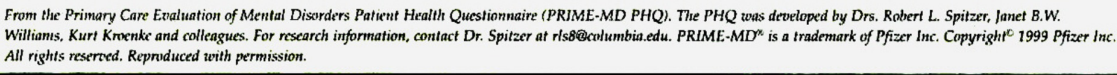 } \\
\hline
\end{tabular}

\section{FIGURE 1: Patient health questionnaire-9 (PHQ-9)}

The questionnaire was asked through a standard protocol and was finalized after performing a pilot study on 25 cases. Patients with mentally or physically unstable conditions, and those with other life-threatening conditions and/or with valvular or septal defects, were excluded from our study while only those with an MI within three months with or without comorbidities (hypertension, diabetes, etc.) were included. None of the patients were on antidepressant treatment. Most of the subjects interviewed were illiterate (62.7\%) or had only completed primary education (19\%) and were unaware of the ways to avoid depression following MI.

Categorical data were presented as frequency and percentages while continuous data was presented in terms of mean and standard deviations. Statistical Package for the Social Sciences (SPSS) version 21 (IBM SPSS, Armonk, New York) was used for analyzing the collected data, and the chi square was then applied to determine the correlation between categorical variables. Patients with a PHQ-9 score of 1-4 were said to have screened negative for depression while those with scores of 5-9, 10-14, 15-19, and 20-27 were said to be suffering from mild, moderate, moderately severe, and severe depression, respectively.

\section{Results}




\section{Cureus}

The total number of individuals that participated in the study were 375 . Table 1 depicts their demographic characteristics which include age, gender, marital status, education, and whether they live alone or not.

\begin{tabular}{|c|c|c|}
\hline Characteristics & Frequency & Percentage \\
\hline \multicolumn{3}{|l|}{ Age } \\
\hline \multicolumn{3}{|l|}{ Mean (SD): $58.18(10.66)$} \\
\hline $37-50$ & 105 & 28 \\
\hline $51-58$ & 90 & 24 \\
\hline 59-65 & 92 & 24.5 \\
\hline $66-90$ & 88 & 23.5 \\
\hline \multicolumn{3}{|l|}{ Gender } \\
\hline Male & 229 & 61 \\
\hline Female & 146 & 39 \\
\hline \multicolumn{3}{|l|}{ Miarital status } \\
\hline Single & 24 & 6.4 \\
\hline Married & 278 & 74.1 \\
\hline Divorced & 12 & 3.2 \\
\hline Widow & 61 & 16.3 \\
\hline \multicolumn{3}{|l|}{ Education } \\
\hline Illiterate (no education) & 235 & 62.7 \\
\hline Primary & 71 & 18.9 \\
\hline Secondary & 46 & 12.3 \\
\hline Graduation & 13 & 3.5 \\
\hline Masters & 10 & 2.7 \\
\hline \multicolumn{3}{|l|}{ Live alone } \\
\hline Yes & 22 & 5.9 \\
\hline No & 353 & 94.1 \\
\hline
\end{tabular}

TABLE 1: Demographics

Subjects were asked about their smoking habits, comorbidities (mainly hypertension and diabetes), and family history of diseases. The results of the responses are shown in Table 2. 


\section{Cureus}

\begin{tabular}{|c|c|c|}
\hline Characteristics & Frequency & Valid Percentage \\
\hline \multicolumn{3}{|l|}{ Smoking habits } \\
\hline Yes & 96 & 25.6 \\
\hline \multicolumn{3}{|l|}{ Packs per day? } \\
\hline $0.1-0.9$ & 14 & 14.6 \\
\hline $1.0-1.4$ & 52 & 54.2 \\
\hline $1.5-1.9$ & 13 & 13.5 \\
\hline $2.0-2.4$ & 17 & 17.7 \\
\hline \multicolumn{3}{|l|}{ For how many years? } \\
\hline $1-19$ years & 35 & 36.5 \\
\hline 20-29 years & 28 & 29.2 \\
\hline $30-55$ years & 33 & 34.4 \\
\hline No & 279 & 74.4 \\
\hline \multicolumn{3}{|l|}{ Diagnosed hypertension } \\
\hline Yes & 324 & 86.4 \\
\hline No & 51 & 13.6 \\
\hline \multicolumn{3}{|l|}{ Diagnosed diabetes mellitus } \\
\hline Yes & 160 & 42.7 \\
\hline No & 215 & 57.3 \\
\hline \multicolumn{3}{|l|}{ Family history } \\
\hline Yes & 261 & 69.6 \\
\hline Hypertension & 107 & 41 \\
\hline Diabetes mellitus & 28 & 10.7 \\
\hline Coronary artery disease (CAD) & 56 & 21.5 \\
\hline No & 114 & 30.4 \\
\hline
\end{tabular}

\section{TABLE 2: Other questions}

Results of the PHQ-9 questionnaire are shown in Figure 2. 


\section{Cureus}

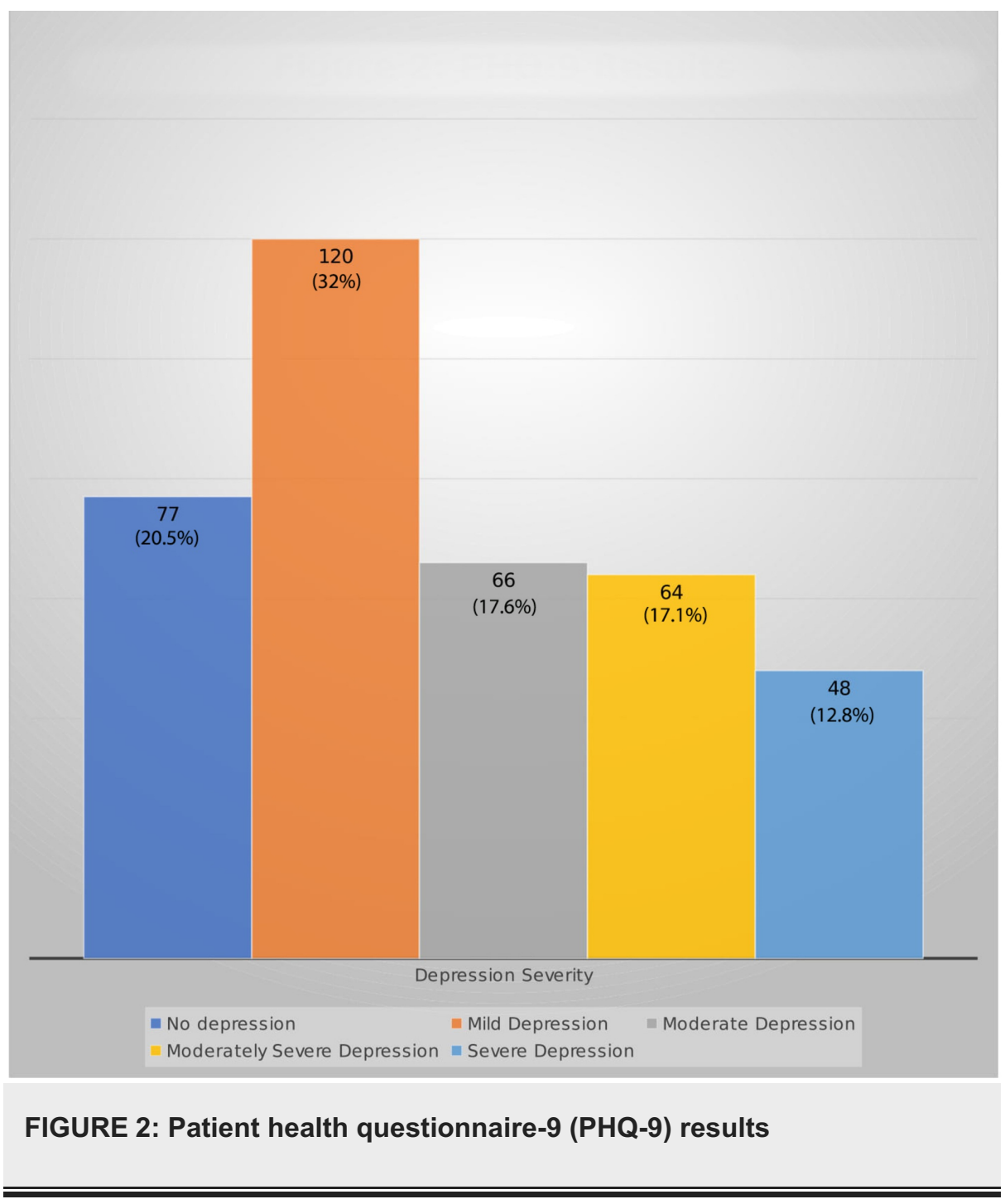

The results of the PHQ-9 were cross-tabbed with age, gender, marital status, living status, smoking, hypertension, and diabetes (Table 3). 


\begin{tabular}{|c|c|c|c|c|c|c|c|}
\hline & $\begin{array}{l}\text { No } \\
\text { Depression } \\
\text { n (\%) }\end{array}$ & $\begin{array}{l}\text { Mild } \\
\text { Depression n } \\
(\%)\end{array}$ & $\begin{array}{l}\text { Moderate } \\
\text { Depression n (\%) }\end{array}$ & $\begin{array}{l}\text { Moderately Severe } \\
\text { Depression n (\%) }\end{array}$ & $\begin{array}{l}\text { Severe } \\
\text { Depression n } \\
(\%)\end{array}$ & $\begin{array}{l}\text { Chi-Square } \\
\text { (p-value) }\end{array}$ & $\begin{array}{l}\text { Total } \\
\mathrm{n}\end{array}$ \\
\hline Age & & & & & & $13.38(0.34)$ & \\
\hline $37-50$ & $21(20)$ & $42(40)$ & 19 (18.1) & 14 (13.3) & $9(8.6)$ & & 105 \\
\hline $51-58$ & 21 (23.3) & 20 (22.2) & $13(14.4)$ & 20 (22.2) & $16(17.8)$ & & 90 \\
\hline $59-65$ & $18(19.6)$ & $31(33.7)$ & $16(17.4)$ & $13(14.1)$ & 14 (15.2) & & 92 \\
\hline $66-90$ & 17 (19.3) & 27 (30.7) & $18(20.5)$ & 17 (19.3) & $9(10.2)$ & & 88 \\
\hline Gender & & & & & & $2.36(0.66)$ & \\
\hline Male & $50(21.8)$ & 67 (29.3) & 40 (17.5) & 41 (17.9) & 31 (13.5) & & 229 \\
\hline Female & 27 (18.5) & $53(36.3)$ & 26 (17.8) & $23(15.8)$ & 17 (11.6) & & 146 \\
\hline $\begin{array}{l}\text { Marital } \\
\text { status }\end{array}$ & & & & & & $19.61(0.07)$ & \\
\hline Single & $5(20.8)$ & $14(58.3)$ & $3(12.5)$ & $2(8.3)$ & 0 & & 24 \\
\hline Married & $61(21.9)$ & $81(29.1)$ & $47(16.9)$ & 50 (18) & $39(14)$ & & 278 \\
\hline Divorced & $3(25)$ & $4(33.3)$ & 0 & 2 (16.7) & $3(25)$ & & 12 \\
\hline Widow & $8(13.1)$ & $21(34.4)$ & $16(26.2)$ & 10 (16.4) & $6(9.8)$ & & 61 \\
\hline Live alone & & & & & & N/A & \\
\hline Yes & $8(36.4)$ & $7(31.8)$ & $3(13.6)$ & $2(9.1)$ & $2(9.1)$ & & 22 \\
\hline No & 69 (19.5) & $113(32)$ & $63(17.8)$ & 62 (17.6) & $46(13)$ & & 353 \\
\hline Smoking & & & & & & $2.08(0.72)$ & \\
\hline Yes & 17 (17.7) & $29(30.2)$ & $16(16.7)$ & $20(20.8)$ & $14(14.6)$ & & 96 \\
\hline No & $60(21.5)$ & 91 (32.6) & $50(17.9)$ & $44(15.8)$ & 34 (12.2) & & 279 \\
\hline Hypertension & & & & & & $3.03(0.55)$ & \\
\hline Yes & 66 (20.4) & 108 (33.3) & $55(17)$ & $56(17.3)$ & $39(12)$ & & 324 \\
\hline No & $11(21.6)$ & $12(23.5)$ & $11(21.6)$ & $8(15.7)$ & $9(17.6)$ & & 51 \\
\hline $\begin{array}{l}\text { Diabetes } \\
\text { mellitus }\end{array}$ & & & & & & $6.05(0.19)$ & \\
\hline Yes & $41(25.6)$ & 50 (31.3) & 22 (13.8) & 26 (16.3) & 21 (13.1) & & 160 \\
\hline No & 36 (16.7) & $70(32.6)$ & $44(20.5$ & $38(17.7)$ & $27(12.6)$ & & 21 \\
\hline
\end{tabular}

\section{TABLE 3: Cross tabulation}

Out of the total 146 female subjects, 119 (81.5\%) were found to be suffering from some degree of depression. On the other hand, 179 (78.2\%) of the 229 males screened positive for some degree of depression. Furthermore, $79(82.3 \%)$ of the 96 smokers were suffering from a range of depression while 219 (78.5\%) of the 279 non-smokers suffered the same.

\section{Discussion}

In past studies, approximately $20 \%$ of the patients hospitalized for ACS met the American Psychiatric Association's Diagnostic and Statistical Manual of Mental Disorders (DSM) criteria for major depression, and an even larger percentage showed subclinical levels of depressive symptoms [22]. In our study, approximately $30 \%$ of the subjects were suffering from moderately severe to severe depression. 
impairment [23], which suggests that depression may exacerbate physical inactivity and poor self-care. This might be a factor in our study as well. However, it is important to recognize that any candidate's mechanism is not mutually exclusive, and multiple potential mechanisms may link depression with adverse outcomes. For instance, a study revealed a significant association between smoking and depressive symptoms [24], but our findings failed to do so.

There is some evidence that depressive episodes that develop soon after an MI may carry a higher risk than episodes that begin before MI. In a study, it was reported that a subgroup of patients who were depressed and/or anxious after the MI and who had denied ever being depressed before the acute event were at increased risk of cardiovascular mortality during the follow-up period [25-26]. Therefore, it is crucial to screen every ACS patient for depression to avoid a delay in the diagnosis and treatment of depression. A recent randomized, controlled trial revealed that a 24-week treatment of depression following recent ACS lowers the risk of major adverse cardiac events after a median of 8.1 years, thereby improving long-term cardiac outcomes [27].

\section{Conclusions}

It is proven from previous studies that treating depression improves long-term survival after MI and that worsening depression increases the risk of adverse clinical outcomes. Moreover, severe or persistent depression is reason enough to consider more comprehensive evaluation and treatment. Further research is needed to determine the risks and benefits of routine screening for depression and to identify safe and effective treatment options for depression in patients with MI.

\section{Additional Information \\ Disclosures}

Human subjects: Consent was obtained by all participants in this study. Institutional Review Board (IRB), Dow University of Health Sciences, Baba-e-Urdu Road, Karachi, Pakistan issued approval -. Approved by Principal of Dow Medical College for conducting research. Animal subjects: All authors have confirmed that this study did not involve animal subjects or tissue. Conflicts of interest: In compliance with the ICMJE uniform disclosure form, all authors declare the following: Payment/services info: All authors have declared that no financial support was received from any organization for the submitted work. Financial relationships: All authors have declared that they have no financial relationships at present or within the previous three years with any organizations that might have an interest in the submitted work. Other relationships: All authors have declared that there are no other relationships or activities that could appear to have influenced the submitted work.

\section{References}

1. Khawaja IS, Westermeyer JJ, Gajwani P, Feinstein RE: Depression and coronary artery disease: the association, mechanisms, and therapeutic implications. Psychiatry (Edgmont). 2009, 6:38-51.

2. Meijer A, Conradi HJ, Bos EH, Thombs BD, van Melle JP, de Jonge P: Prognostic association of depression following myocardial infarction with mortality and cardiovascular events: a meta-analysis of 25 years of research. Gen Hosp Psychiatry. 2011, 30:203-16. 10.1016/j.genhosppsych.2011.02.007

3. Meijer A, Conradi HJ, Bos EH, et al.: Adjusted prognostic association of depression following myocardial infarction with mortality and cardiovascular events: individual patient data meta-analysis. Br J Psychiatry. 2013, 203:90-102. 10.1192/bjp.bp.112.111195

4. Sherwood A, Hinderliter AL, Watkins LL, Waugh RA, Blumenthal JA: Impaired endothelial function in coronary heart disease patients with depressive symptomatology. J Am Coll Cardiol. 2005, 4:656-659. 10.1016/j.jacc.2005.05.041

5. Von Känel R: Platelet hyperactivity in clinical depression and the beneficial effect of antidepressant drug treatment: how strong is the evidence?. Acta Psychiatr Scand. 2004, 110:163-177. 10.1111/j.16000447.2004.00308.x

6. Empana JP, Sykes DH, Luc G, et al.: Contributions of depressive mood and circulating inflammatory markers to coronary heart disease in healthy European men. Circulation. 2005, 111:2299-2305. 10.1161/01.CIR.0000164203.54111.AE

7. Lespérance F, Frasure-Smith N, Théroux P, Irwin M: The association between major depression and levels of soluble intercellular adhesion molecule 1, interleukin-6, and C-reactive protein in patients with recent acute coronary syndromes. Am J Psychiatry. 2004, 161:271-277. 10.1176/appi.ajp.161.2.271

8. Vaccarino V, Johnson BD, Sheps DS, et al.: Depression, inflammation, and incident cardiovascular disease in women with suspected coronary ischemia: the National Heart, Lung, and Blood Institute-sponsored WISE study. J Am Coll Cardiol. 2007, 50:2044-2050. 10.1016/j.jacc.2007.07.069

9. Lichtman JH, Froelicher ES, Blumenthal JA, et al.: Depression as a risk factor for poor prognosis among patients with acute coronary syndrome: systematic review and recommendations a scientific statement from the American Heart Association. Circulation. 2014, 129:1350-1369. 10.1161/CIR.0000000000000019

10. Skala JA, Freedland KE, Carney RM: Coronary heart disease and depression: a review of recent mechanistic research. Can J Psychiatry. 2006, 51:738-745. 10.1177/070674370605101203

11. Carney RM, Freedland KE, Miller GE, Jaffe AS: Depression as a risk factor for cardiac mortality and morbidity: a review of potential mechanisms. J. Psychosom Res. 2002, 53:897-902. 10.1016/S00223999(02)00311-2

12. Nicholson A, Kuper H, Hemingway H: Depression as an aetiologic and prognostic factor in coronary heart 
disease: a meta-analysis of 6362 events among 146538 participants in 54 observational studies. Eur Heart J. 2006, 27:2763-2774. 10.1093/eurheartj/ehl338

13. Carney RM, Howells WB, Blumenthal JA, et al.: Heart rate turbulence, depression, and survival after acute myocardial infarction. Psychosom Med. 2007, 69:4-9. 10.1097/01.psy.0000249733.33811.00

14. Carney RM, Freedland KE, Veith RC: Depression, the autonomic nervous system, and coronary heart disease . Psychosom. Med.. 2005, 67:S29-S33. 10.1097/01.psy.0000162254.61556.d5

15. Carney RM, Blumenthal JA, Freedland KE, et al.: Low heart rate variability and the effect of depression on post-myocardial infarction mortality. JAMA Intern Med. 2005, 165:1486-1491. 10.1001/archinte.165.13.1486

16. Carney RM, Freedland KE, Veith RC, Cryer PE, Skala JA, Lynch T, Jaffe AS: Major depression, heart rate, and plasma norepinephrine in patients with coronary heart disease. Biol Psychiatry. 1999, 45:458-463. 10.1016/S0006-3223(98)00049-3

17. Leo Pozuelo: Depression \& Heart Disease. Cleveland Clinic Website. Accessed on 7/20/2018.

18. Lichtman JH, Bigger JT Jr, Blumenthal JA, et al.: AHA science advisory. depression and coronary heart disease. Recommendations for screening, referral, and treatment. A science advisory from the American Heart Association Prevention Committee to the Council on Cardiovascular Nursing, Council on Clinical Cardiology, Council on Epidemiology and Prevention, and Interdisciplinary Council on Quality of Care Outcomes Research. Endorsed by the American Psychiatric Association. Europe PMC. 2009, 1:19-26. 10.1111/j.1751-7117.2009.00028.x

19. Rugulies R: Depression as a predictor for coronary heart disease: a review and meta-analysis . Am J Prev Med. 2002, 1:51-61. 10.1016/S0749-3797(02)00439-7

20. Egede LE: Major depression in individuals with chronic medical disorders: prevalence, correlates and association with health resource utilization, lost productivity and functional disability. Gen Hosp Psychiatry. 2007, 29:409-416. 10.1016/j.genhosppsych.2007.06.002

21. Open Source Epidemiologic Statistics for Public Health, Version 3.01 . (2013). Accessed: 21 August 2018: http://www.openepi.com/SampleSize/SSPropor.htm.

22. Kroenke K, Spitzer RL, Williams JB: The Phq-9. J Gen Intern Med. 2001, 16:606-613. 10.1046/j.15251497.2001.016009606.x

23. Ruo B, Rumsfeld JS, Hlatky MA, Liu H, Browner WS, Whooley MA: Depressive symptoms and health-related quality of life: the heart and soul study. JAMA. 2003, 290:215-221. 10.1001/jama.290.2.215

24. Whooley MA, de Jonge P, Vittinghoff E, et al.: Depressive symptoms, health behaviors, and risk of cardiovascular events in patients with coronary heart disease. JAMA. 2008, 300:2379-2388. 10.1001/jama.2008.711

25. de Jonge P, van den Brink RH, Spijkerman TA, Ormel J: Only incident depressive episodes after myocardial infarction are associated with new cardiovascular events. J Am Coll Cardiol. 2006, 48:2204-2208. 10.1016/j.jacc.2006.06.077

26. Dickens C, McGowan L, Percival C, et al.: New onset depression following myocardial infarction predicts cardiac mortality. Psychosomatic Medicine. 2008, 70:450-455. 10.1097/PSY.0b013e31816a74de

27. Kim JM, Stewart R, Lee YS, et al.: Effect of escitalopram vs placebo treatment for depression on long-term cardiac outcomes in patients with acute coronary syndrome: a randomized clinical trial. JAMA. 2018, 320:350-358. 10.1001/jama.2018.9422 